\title{
CrimRxiv
}

\section{Can whale-fall studies inform human forensics?}

Fiona Juniper, Brett D. Jameson, S. Kim Juniper, Craig R. Smith, Lynne S. Bell

Published on: Jul 10, 2021

License: Creative Commons Attribution 4.0 International License (CC-BY 4.0). 
